\title{
Correlation between grain yield in maize plant densities
}

\section{Correlação entre produtividade de grãos em densidades populacionais de milho}

\author{
Luiz Augusto da Costa GAZOTTO'; Kauê CHARNAI²; Lucélia de Fátima SANTOS 3 ; \\ Maisa Nascimento CARVALHO ${ }^{3}$; Gustavo Vitti MÔRO ${ }^{4}$
}

${ }^{1}$ Engenheiro agrônomo - FCAV/UNESP - luiz.gazotto@hotmail.com

${ }^{2}$ Engenheiro agrônomo, Mestre em Agronomia (Genética e Melhoramento de Plantas - FCAV/UNESP, GDM Genética do Brasil S.A. - kaue_shera@hotmail.com

${ }^{3}$ Mestrandas em Agronomia (Genética e Melhoramento de Plantas) da UNESP/FCAV - luceliasantos98@hotmail.com, maisa.n.c@hotmail.com

${ }^{4}$ Autor para correspondência - Professor Associado, Departamento de Ciências da Produção Agrícola - FCAV/UNESP gv.moro@unesp.br

\begin{abstract}
When assessing genotypes in different environments, the result depends on the genotype-environment interaction. Among the environmental factors, the spatial arrangement of plants is among the most important management practices to achieve higher grain yield. This arrangement involves changes in the spacing between rows and between plants. The present study evaluates the correlation between the grain yield of maize genotypes and different plant populations. We conducted the experiments in the 2012/2013 harvest season and in the 2012/13 offseasons at UNESP - Jaboticabal Campus, in Jaboticabal county, São Paulo State, Brazil, and in the 2013 offseason at Cambuhy Farm, in Matão county, São Paulo State, Brazil. The experimental design was in randomized blocks, with three replicates. For the $0.50 \mathrm{~m}$ spacing between rows, the spacing between plants was $0.25 \mathrm{~m}$

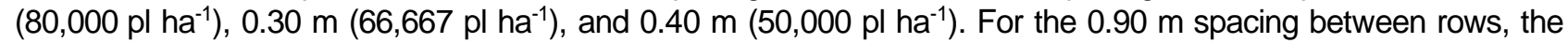
spacing between plants was $0.20 \mathrm{~m}\left(55,556 \mathrm{pl} \mathrm{ha}^{-1}\right)$. We assessed the treatments for grain yield (six genotypes), analyzing the correlations between grain yield averages and plant population densities for each environment using the Pearson correlation coefficient. The 2012/2013 harvest season in Jaboticabal county provided the highest average yield, regardless of population density. The 2012 off-season in Jaboticabal county provided the lowest average yield. As for population densities, the one that provided the highest yield was 80,000 plants ha-1. The present study found several types of correlation, which allows us to say that population density recommendations must be specific.
\end{abstract}

Recebido em: 08-05-2020; Aceito em: 18-06-2020

Additional keywords: genotype x environment interaction; sowing times; spacing; Zea mays L.

\section{Resumo}

Quando genótipos são avaliados em ambientes distintos, o resultado depende da interação genótipo-ambiente. Dentre os fatores ambientais, o arranjo espacial de plantas está entre as práticas de manejo mais importantes para se alcançar maior produtividade de grãos, pela alteração no espaçamento entre linhas e entre plantas. Por isso, objetivou-se avaliar a correlação entre a produtividade de grãos de genótipos de milho e densidades populacionais. Os experimentos foram desenvolvidos na safra 2012/2013 e safrinhas 2012 e 2013 na UNESP, Câmpus de Jaboticabal - SP, e na safrinha 2013 na Fazenda Cambuhy, Matão - SP. O delineamento experimental foi em blocos casualizados, com três repetições. No espaçamento de $0,50 \mathrm{~m}$ entre linhas, o espaçamento entre plantas foi de $0,25 \mathrm{~m}\left(80.000 \mathrm{pl} \mathrm{ha}^{-1}\right), 0,30 \mathrm{~m}\left(66.667 \mathrm{pl} \mathrm{ha}^{-1}\right)$ e $0,40 \mathrm{~m}\left(50.000 \mathrm{pl} \mathrm{ha}^{-1}\right)$. Para o espaçamento de $0,90 \mathrm{~m}$ entre linhas, o espaçamento entre plantas foi de $0,20 \mathrm{~m}\left(55.556 \mathrm{pl} \mathrm{ha}^{-1}\right)$. Os tratamentos utilizados (seis genótipos) foram avaliados quanto a produtividade de grãos e foram analisadas as correlações entre as médias de produtividade obtidas e as densidades populacionais para cada ambiente usando-se do Coeficiente de Correlação de Pearson. A safra Jaboticabal 2012/2013 proporcionou a maior média de produtividade, independentemente da densidade populacional. A safrinha Jaboticabal 2012 forneceu a menor média de produtividade. Quanto as densidades populacionais, aquela que conferiu maior produtividade foi a de $80.000 \mathrm{pl} \mathrm{ha}^{-1}$. Diversos tipos de correlação foram encontrados, o que permite dizer que recomendações de densidade populacional devem ser específicas.

Palavras-chave adicionais: épocas de semeadura; espaçamento; interação genótipo x ambiente, Zea mays L.. 


\section{Introduction}

Maize (Zea mays L.) is among the main grain producing crops in the world, ranking first in production and yield, and third in planted area. Estimates for the $2019 / 2020$ agricultural year point to the worldwide production of 1.11 billion tons of maize (USDA, 2020). Of this total, Brazil may account for 101.9 million tons, making the country the third largest world producer of this cereal (CONAB, 2020).

In Brazil, estimates for maize production in the 2019/20 harvest season, considering the first, second, and third harvests, include a planted area of 18.2 million hectares, providing the aforementioned production of 101.9 million tons (CONAB, 2020).

Regarding the destination of the Brazilian production of maize grains, the product can remain on the rural property for animal consumption or be directed to feed factories, chemical industries, fresh consumption market, and exports. Industrial processing can transform the grain into oil, flour, starch, margarine, glucose syrup, and flakes for breakfast cereals. However, the main destination of maize grains is animal feed, accounting for $70 \%$ of the world's production and 70 $80 \%$ of the Brazilian production (EMBRAPA, 2012).

Because of its relevance, maize has been the subject of research in Brazil and worldwide. At first, farmers used open pollination varieties as commercial cultivars. Then, with the discovery of hybrid vigor (Shull, 1909; East, 1909), which led to consecutive yield records for maize, farmers started to use this type of genotype in their crops. Genetic breeding programs of several public and private institutions develop different varieties and hybrids aiming not only at greater yield, but also at desirable agronomic characteristics. Thus, in addition to the direct use of open pollination varieties of maize as cultivars, they can be sources of genetic variability in breeding programs.

Environmental conditions influence the phenotypic response, but in the case of two or more genotypes and environments, the result will depend on the interaction between genetic and environmental factors, among which management has a great influence. In this sense, the spatial arrangement of plants is one of the most important management practices. The change in spacing between and within rows can optimize the use of factors such as water, light, and nutrients, increasing crop yield (Pellizzaro et al., 2019).

With the launch of modern, more productive maize cultivars, with lower plant height, lower ear insertion height, less sterility, shorter bolting/silking period, and more upright leaves, it becomes necessary to reevaluate the management practices of the maize crop (Kappes et al., 2011; Bettio et al., 2017) to understand how the spatial arrangement may alter the yield of genotypes. This type of study also indicates the need to evaluate genotypes in different spatial arrangements, or the possibility of predicting genotypes in different arrangements.

Studies usually address the degree of association between two or more variables, which can be, for example, characteristics or environments. To estimate the degree of association between variables, research- ers use the correlation coefficient. Simple correlation is an option for this type of study, for which researchers can use the Pearson linear correlation coefficient (Lira \& Chaves Neto, 2006).

This study evaluates the correlation between maize grain yield in different plant densities.

\section{Material and methods}

We conducted the experiments at UNESP Jaboticabal Campus, in Jaboticabal county, São Paulo State, Brazil, and at the Cambuhy farm, in Matão county, São Paulo State, Brazil.

Jaboticabal county is located in the northeast region of São Paulo State $\left(21^{\circ} 14^{\prime} 05^{\prime \prime} S\right.$ latitude, $48^{\circ} 17^{\prime} 09^{\prime \prime}$ W longitude; altitude of $615.01 \mathrm{~m}$ ). Its climate is tropical $(A w)$, with average annual temperature of $22.2^{\circ} \mathrm{C}$ and average annual rainfall of $1400 \mathrm{~mm}$. The soil of the experimental area in this region is a eutroferric Red Latosol (Andrioli \& Centurion, 1999). In turn, Matão county, also constituting the northeast of São Paulo State, is located at $21^{\circ} 36^{\prime} 00^{\prime \prime}$ S latitude, $48^{\circ} 21^{\prime} 41^{\prime \prime}$ W longitude, at an altitude of $582 \mathrm{~m}$. According to the Köppen classification (1948), the climate in the region is tropical $(\mathrm{Aw})$, with average annual temperature of $23.5^{\circ}$ $\mathrm{C}$ and average annual rainfall of $1400 \mathrm{~mm}$. The soil of the experimental area in this region is a eutrophic Red Yellow Argisol.

The experiment took place in two agricultural years, considering both the season and the off-season crops. We considered each combination between year and sowing time as a different environment. In Jaboticabal county, we conducted experiments in the 2012/2013 harvest season and in the 2012 and 2013 off-seasons. The sowing of these experiments took place on 11/21/2012, 04/17/2012, and 02/15/2013, respectively. In Matão county, sowing took place in the 2013 off-season, on 01/22/2013.

We installed four experiments in each environment, three with $0.50 \mathrm{~m}$ spacing between rows and one with $0.90 \mathrm{~m}$ spacing between rows. The experimental design was in randomized blocks, with three replicates. Plots consisted of four and eight 5-m long rows, respectively, for the spacing of $0.90 \mathrm{~m}$ and $0.50 \mathrm{~m}$ between rows. The useful plot consisted of the two central rows.

For the spacing of $0.50 \mathrm{~m}$ between rows, we used the following spacings between plants: $0.25 \mathrm{~m}$ $\left(80,000 \mathrm{pl} \mathrm{ha}^{-1}\right), 0.30 \mathrm{~m}\left(66,667 \mathrm{pl} \mathrm{ha}^{-1}\right)$, and $0.40 \mathrm{~m}$ $\left(50,000 \mathrm{pl} \mathrm{ha}^{-1}\right)$. For the $0.90 \mathrm{~m}$ spacing between rows, we used the $0.20 \mathrm{~m}$ spacing between plants $\left(55,556 \mathrm{pl} \mathrm{ha}^{-1}\right)$, totaling four population densities.

The genotypes used in the experiments were the experimental maize varieties DSS-0401, DSS-0402, and DSS-0404, from the company Di Solo Sementes, and the commercial maize varieties AL Bandeirantes Di Solo, AL Bandeirantes CATI, and Ipanema. In each useful plot, we assessed genotypes for grain yield (GY). For that, we weighed the grains of plants in the plot and 
adjusted the values to $13 \%$ moisture, expressing the values in kilograms per hectare $\left(\mathrm{kg} \mathrm{ha}^{-1}\right)$.

For each density and environment, we submitted yield data to individual analysis of variance using the Genes software, version 2013 (Cruz, 2006). After obtaining the averages, we estimated Pearson correlations between yield and plant density for each environment according to the following mathematical model:

$$
r=\frac{C j j^{\prime}}{S j S j^{\prime}}
$$

Wherein: $\mathrm{C}_{\mathrm{j}, \mathrm{j}}$ : is the covariance or joint variance between densities $\mathrm{j}$ and $\mathrm{j}^{\prime} ; \mathrm{S}_{\mathrm{j}}, \mathrm{S}_{\mathrm{j}}$ : is the standard deviation of densities $\mathrm{j}$ and $\mathrm{j}$ ', respectively.

\section{Results and discussion}

Table 1 shows the results of the analysis of individual variance for the experimental densities. The results (Table 1) for yield show a significant difference at $5 \%$ probability level between genotypes at the density of $80,000 \mathrm{pl} \mathrm{ha}^{-1}$ in the $2012 / 2013$ harvest season in Jaboticabal county and in the 2013 off-season in Matão county. At the density of $55,556 \mathrm{pl} \mathrm{ha}^{-1}$ in the 2012 offseason in Jaboticabal county, there was a significant difference at $1 \%$ probability level.

Table 1 - Summary of the analysis of variance for the grain yield $\left(\mathrm{kg} \mathrm{ha}^{-1}\right)$ in the four environments evaluated for densities of $80,000,66,667,55,556$ and 50,000 plants per hectare, respectively, in maize varieties.

\begin{tabular}{|c|c|c|c|c|}
\hline \multirow{3}{*}{ Sources of variation } & \multicolumn{4}{|c|}{ Grain yield $\left(\mathrm{kg} \mathrm{ha}^{-1}\right)$} \\
\hline & $\begin{array}{c}\text { Jaboticabal 2012/13 } \\
\text { Season }\end{array}$ & $\begin{array}{c}\text { Jaboticabal } 2012 \\
\text { Off season }\end{array}$ & $\begin{array}{c}\text { Jaboticabal } 2013 \\
\text { Off season }\end{array}$ & $\begin{array}{l}\text { Matão } 2013 \\
\text { Off season }\end{array}$ \\
\hline & \multicolumn{4}{|c|}{80,000 plants ha ${ }^{-1}$} \\
\hline MS - Genotypes & $2,887,892.49^{*}$ & $442,939.70^{\text {ns }}$ & $3,427,891.93^{\text {ns }}$ & $14,541,968.83^{*}$ \\
\hline Mean & 9,758 & 5,240 & 7,826 & 7,553 \\
\hline CV (\%) & 8.10 & 20.74 & 17.15 & 26.30 \\
\hline \multirow[t]{2}{*}{$\mathrm{CVg} / \mathrm{CVe}$} & 1.10 & 0.00 & 0.55 & 0.95 \\
\hline & \multicolumn{4}{|c|}{66,667 plants ha ${ }^{-1}$} \\
\hline MS - Genotypes & $1,307,637.49^{\text {ns }}$ & $333,928.15^{\text {ns }}$ & $2,147,106.59^{n s}$ & $2,805,285.58^{\text {ns }}$ \\
\hline Mean & 8,240 & 4,648 & 6,828 & 5,737 \\
\hline CV (\%) & 14.54 & 17.39 & 13.66 & 23.29 \\
\hline \multirow[t]{2}{*}{$\mathrm{CVg} / \mathrm{CVe}$} & 0.00 & 0.00 & 0.700 & 0.436 \\
\hline & \multicolumn{4}{|c|}{55,556 plants ha ${ }^{-1}$} \\
\hline MS - Genotypes & $1,588,754.12^{\text {ns }}$ & $445,992.29^{* * *}$ & $661,165.41^{\text {ns }}$ & $783,904.18^{\text {ns }}$ \\
\hline Mean & 8,646 & 3,765 & 6,502 & 4,079 \\
\hline CV (\%) & 12.15 & 5.94 & 8.26 & 37.10 \\
\hline \multirow{2}{*}{$\mathrm{CVg} / \mathrm{CVe}$} & 0.382 & 1.625 & 0.656 & 0.00 \\
\hline & \multicolumn{4}{|c|}{50,000 plants ha $^{-1}$} \\
\hline MS - Genotypes & $1,532,695.95^{\mathrm{ns}}$ & $353,358.98^{\text {ns }}$ & $2,310,266.12^{\text {ns }}$ & $4,014,937.79^{\text {ns }}$ \\
\hline Mean & 8,063 & 3,633 & 6,029 & 5,690 \\
\hline CV (\%) & 19.62 & 18.10 & 17.65 & 21.67 \\
\hline $\mathrm{CVg} / \mathrm{CVe}$ & 0.00 & 0.00 & 0.589 & 0.740 \\
\hline
\end{tabular}

$\mathrm{MS} .=$ Mean square; $\mathrm{CV}=$ Coefficient of variation; $\mathrm{CVg}=$ Coefficient of genetic variation; $\mathrm{CVe}=$ Coefficient of experimental variation, ${ }^{*}$ and ${ }^{* *}$ Significant to $5 \%$ and $1 \%$ of probability by $\mathrm{F}$ test, respectively.

The coefficients of variation in all densities in the 2013 off-season in Matão county, in the density of $80,000 \mathrm{pl} \mathrm{ha}^{-1}$ in the 2012 off-season in Jaboticabal county, and in the density of $50,000 \mathrm{pl} \mathrm{ha}^{-1}$ in the 2012/2013 harvest season in Jaboticabal county were above $19 \%$, which researchers consider too high for the trait. According to Fritsche-Neto et al. (2012), the classification ranges of coefficients of variation are unique for each variable.

Another important source of variation is the $\mathrm{CVg} / \mathrm{CVe}$ ratio, which was above 1.0 in the densities of $80,000 \mathrm{pl} \mathrm{ha}^{-1}$ in the $2012 / 2013$ harvest season in Jaboticabal county and 55,556 pl ha ${ }^{-1}$ in the 2012 offseason in Jaboticabal county. The density of $80,000 \mathrm{pl}$ ha $^{-1}$ in the 2013 off-season in Matão county showed a similar value. This reveals that the expression of the genotype equaled or surpassed the environment, thus favoring genetic selection (Cruz \& Regazzi, 1997).
In general, Table 1 shows the highest yield averages for the 2012/2013 harvest season in Jaboticabal county, regardless of population density. For maize, the interaction between soil and climate is the determining factor for obtaining high yields. Therefore, the harvest season has better environmental conditions than the off-season. The highest yield average corresponded to the 2012/2013 harvest season in Jaboticabal county, $9758.17 \mathrm{~kg} \mathrm{ha}^{-1}$ with $80,000 \mathrm{pl} \mathrm{ha}^{-1}$, followed by the averages achieved with 55,556, 66,667, and $50,000 \mathrm{pl} \mathrm{ha}^{-1}$, respectively, in this same environment.

The second-best average corresponded to the 2013 off-season in Jaboticabal county, in all population densities. The highest yield average of the 2013 off-season in Jaboticabal county $\left(7,826.13 \mathrm{~kg} \mathrm{ha}^{-1}\right)$ corresponded, again, to the plant population of $80,000 \mathrm{pl} \mathrm{ha}^{-1}$, followed by the averages reached with the densities of $66,667,55,556$, and $50,000 \mathrm{pl} \mathrm{ha}^{-1}$, respectively. 
The 2013 off-season in Matão county was the environment that provided the third highest yield average, in all population densities. Even though the 2013 off-season in Jaboticabal county corresponded to the same period of the off-season in Matão county, the first environment always obtained greater results, possibly due to more favorable edaphoclimatic conditions. Despite the proximity between the cities, rainfall is not the same; moreover, the sowing dates of the experiments differed by 25 days. The highest average for the 2013 off-season in Matão county $\left(7,553.00 \mathrm{~kg} \mathrm{ha}^{-1}\right)$ corresponded, again, to the density of $80,000 \mathrm{pl} \mathrm{ha}^{-1}$, followed by the averages obtained with the densities of 66,667 , 50,000 , and $55,556 \mathrm{pl} \mathrm{ha}^{-1}$, respectively.

In particular, the 2012 off-season in Jaboticabal county was the environment with the lowest averages for any density. This result is probably due, again, to the climate factor since the environmental conditions of the off-season are not as ideal as those of the harvest season. During the year of 2012, the present study observed only this off-season, which showed rainfall accumulation of about $90 \mathrm{~mm}$ and average temperature of $20.4 \stackrel{\circ}{\circ}$.

Even though the off-season may occur at the same time of the year, different years may present different climate outcomes in the same location and in the same period. In the case of the 2012 off-season in Jaboticabal county, sowing took place in the second half of April. This is a late period in comparison to other off-seasons, with unfavorable climatic conditions. The highest average at this period $\left(5,240.14 \mathrm{~kg} \mathrm{ha}^{-1}\right)$ also corresponded to the plant density of $80,000 \mathrm{pl} \mathrm{ha}^{-1}$, followed by the averages achieved with the densities of $66,667,55,556$, and $50,000 \mathrm{pl} \mathrm{ha}^{-1}$, respectively.

The results of the present study confirm that, in addition to the edaphoclimatic conditions, plant density affects grain yield considerably. The likely effect of plant density is the change in the architecture of plants and in their growth and development, resulting in different levels of grain yield (Almeida et al., 2000).

Plant densities and their respective yield averages show that there is no linearity between the results. This is probably due to the interaction between genotypes and environments, where genetic materials behave differently under different environmental conditions.

Because grain yield is the object of study in this research, it is noteworthy that this trait usually presents a complex interaction, with lack of dependence between the performance of genotypes in different environments (Vencovsky \& Barriga, 1992). Furthermore, many genes govern this trait. Thus, grain yield proves to be very important both for the improvement of plants and for cultivation recommendations (Baker, 1988; Crossa \& Cornelius, 1997; Lima \& Borém, 2018), requiring experiments in different environments.

The correlation analysis is a tool that enables identifying the degree of relationship between the densities under study, making it possible to reduce the number and/or the size of experiments. Table 2 shows the results for the correlation between yield averages and population densities for each environment.

Table 2 - Pearson's correlation coefficient between grain yield in population densities, for the Jaboticabal 2012/2013, Jaboticabal 2012, Jaboticabal 2013 and Matão 2013 experiments.

\begin{tabular}{|c|c|c|c|c|}
\hline \multirow{6}{*}{$\begin{array}{l}80,000 \mathrm{pl} \mathrm{ha}^{-1} \\
66,667 \mathrm{pl} \mathrm{ha}^{-1} \\
55,556 \mathrm{pl} \mathrm{ha}^{-1} \\
50,000 \mathrm{pl} \mathrm{ha}^{-1}\end{array}$} & \multicolumn{4}{|c|}{ Jaboticabal 2012/2013 Season } \\
\hline & $80,000 \mathrm{pl} \mathrm{ha}^{-1}$ & $66,667 \mathrm{pl} \mathrm{ha}^{-1}$ & $55,556 \mathrm{pl} \mathrm{ha}^{-1}$ & $50,000 \mathrm{pl} \mathrm{ha}^{-1}$ \\
\hline & 1.00 & 0.20 & 0.04 & 0.18 \\
\hline & & \multirow[t]{3}{*}{1.00} & 0.94 & 0.74 \\
\hline & & & \multirow[t]{2}{*}{1.00} & 0.55 \\
\hline & & & & 1.00 \\
\hline & \multicolumn{4}{|c|}{ Jaboticabal 2012 Off-season } \\
\hline & $80,000 \mathrm{pl} \mathrm{ha}^{-1}$ & $66,667 \mathrm{pl} \mathrm{ha}^{-1}$ & $55,556 \mathrm{pl} \mathrm{ha}^{-1}$ & $50,000 \mathrm{pl} \mathrm{ha}^{-1}$ \\
\hline $80,000 \mathrm{pl} \mathrm{ha}^{-1}$ & 1.00 & -0.02 & -0.71 & 0.49 \\
\hline $66,667 \mathrm{pl} \mathrm{ha}^{-1}$ & & 1.00 & 0.64 & -0.47 \\
\hline $55,556 \mathrm{pl} \mathrm{ha}^{-1}$ & & & 1.00 & -0.59 \\
\hline \multirow[t]{3}{*}{$50,000 \mathrm{pl} \mathrm{ha}^{-1}$} & & & & 1.00 \\
\hline & \multicolumn{4}{|c|}{ Jaboticabal 2013 Off-season } \\
\hline & $80,000 \mathrm{pl} \mathrm{ha}^{-1}$ & $66,667 \mathrm{pl} \mathrm{ha}^{-1}$ & $55,556 \mathrm{pl} \mathrm{ha}^{-1}$ & $50,000 \mathrm{pl} \mathrm{ha}^{-1}$ \\
\hline $80,000 \mathrm{pl} \mathrm{ha}^{-1}$ & 1.00 & -0.21 & 0.52 & -0.56 \\
\hline $66,667 \mathrm{pl} \mathrm{ha}^{-1}$ & & 1.00 & -0.41 & 0.19 \\
\hline $55,556 \mathrm{pl} \mathrm{ha}^{-1}$ & & & 1.00 & -0.67 \\
\hline \multirow[t]{3}{*}{$50,000 \mathrm{pl} \mathrm{ha}^{-1}$} & & & & 1.00 \\
\hline & \multicolumn{4}{|c|}{ Matão 2013 Off-season } \\
\hline & $80,000 \mathrm{pl} \mathrm{ha}^{-1}$ & $66,667 \mathrm{pl} \mathrm{ha}^{-1}$ & $55,556 \mathrm{pl} \mathrm{ha}^{-1}$ & $50,000 \mathrm{pl} \mathrm{ha}^{-1}$ \\
\hline $80,000 \mathrm{pl} \mathrm{ha}^{-1}$ & 1.00 & 0.17 & -0.15 & -0.57 \\
\hline $66,667 \mathrm{pl} \mathrm{ha}^{-1}$ & & 1.00 & 0.14 & -0.55 \\
\hline $55,556 \mathrm{pl} \mathrm{ha}^{-1}$ & & & 1.00 & 0.59 \\
\hline $50,000 \mathrm{pl} \mathrm{ha}^{-1}$ & & & & 1.00 \\
\hline
\end{tabular}


From the results of the 2012/2013 harvest season in Jaboticabal county and following the classification by Callegari-Jacques (2003), the experiments showed a very strong positive linear correlation between the averages achieved with the densities of 66,667 and $55,556 \mathrm{pl} \mathrm{ha}^{-1}$. The densities of 66,667 and $50,000 \mathrm{pl} \mathrm{ha}^{-1}$ also showed strong positive linear correlation. The 2012 off-season in Jaboticabal county showed a strong negative correlation between the densities of 80,000 and $55,556 \mathrm{pl} \mathrm{ha}^{-1}$, and a strong positive correlation between the densities of 66,667 and $55,556 \mathrm{pl} \mathrm{ha}^{-1}$. The 2013 off-season in Jaboticabal county showed a strong negative correlation only between the densities of 50,000 and 55,556 pl ha-1. Regarding the 2013 off-season in Matão county, the experimental densities did not show neither strong nor very strong correlation.

In a final analysis, poor correlation between densities means that the genotypes present different performance, requiring an assessment of their performance in each of the densities.

In the case of high correlation between densities, the genotypes show a very similar behavior. In this situation, one can choose to conduct experiments in the same environment with only one of the two densities, as the behavior will be the same for the other density in this same environment. Hence, the researcher should choose the most advantageous situation (Peluzio et al., 2012).

A strong positive correlation means that the yield increase in a given population density also occurred in the other experimental density. In the case of a strong negative correlation, the conditions that increased yield at a certain density are not the same for the other density, with a decrease in the trait.

Moreover, the correlations varied according to the environment, suggesting the occurrence of genotype $x$ environment (GxE) interaction. This prevents the extrapolation of results of the correlation between densities for all environments.

\section{Conclusions}

The present study found a correlation between population density and grain yield in the four environments, showing the importance of making specific recommendations.

Different environments influence the correlation between densities, preventing the extrapolation of results in terms of population density alone.

\section{References}

Almeida ML, Merotto Júnior A, Sangoi L, Emder M, Guidolin AF (2000) Incremento na densidade de plantas: uma alternativa para aumentar o rendimento de grãos de milho em regiões de curta estação estival de crescimento. Ciência Rural 30(1):23-29.
Andrioli I, Centurion JF (1999) Levantamento detalhado dos solos da Faculdade de Ciências Agrárias e Veterinárias de Jaboticabal. In: Congresso Brasileiro de Ciência do Solo, Brasília. Anais... Brasília-DF: Sociedade Brasileira de Ciência do Solo, p.1-4.

Baker RJ (1988) Tests for crossover genotype-environmental interactions. Canadian Journal of Plant Science, 68(2):405-410.

Bettio CS, Ganascini D, Wunsh CA, Renosto L, Maggi MF, Gurgacz F (2017) Produtividade do milho (Zea mays L.) com diferentes arranjos populacionais em linhas simples e duplas. Acta Iguazu 6(3):44-51.

Callegari-Jacques SM (2003) Bioestatística: princípios e aplicações. Artmed Editora. 255 p.

CONAB (2020) Companhia Nacional de Abastecimento. Acompanhamento da Safra Brasileira Grãos, Safra 2019/20, 7(7). Disponível em: https://www.conab.gov.br/info-

agro/safras/graos/boletim-da-safra-de-graos. (Acesso em 30 abril. 2020).

Crossa J, Cornelius PL (1997) Sites regression and shifted multiplicative model clustering of cultivar trial sites under heterogeneity of error variances. Crop Science 37(2):406-415.

Cruz CD (2006) Programa Genes: Biometria. UFV. 382 p.

Cruz CD, Regazzi AJ (1997) Modelos biométricos aplicados ao melhoramento genético. UFV. 394p.

East EM (1909) The distinction between development and heredity in inbreeding. The American Naturalist 43(507):173-181.

EMBRAPA (2012) Cultivo do milho. Disponível em: $<$ https://www.spo.cnptia.embrapa.br/conteudo?p_p_id $=$ conteudoportlet_WAR_sistemasdeproducaolf6_1 1 ga 1 ceportlet\&p_p_lifecycle $=0 \& p \_p \_s t a t e=n o r m a l \& p \_p \_m$ ode=view\&p_p_col $i d=$ column-

$1 \& p \_p \_c o l \_c o u n t=1 \& p \_r \_p$ -

76293187_sistemaProducaold $=3821 \& p \_r \_p$ 996514994_topicold=3716> (Acesso em 08 jun. 2014).

Fritsche-Neto R, Vieira RA, Scapim CA, Miranda GV, Rezende LM (2012) Updating the ranking of the coefficients of variation from maize experiments. Acta Scientiarum. Agronomy 34(1):99-101.

Kappes C, Andrade JADC, Arf O, Oliveira ÂCD, Arf MV, Ferreira JP (2011) Arranjo de plantas para diferentes híbridos de milho. Pesquisa Agropecuária Tropical 41(3):348-359.

Köppen W (1948) Climatología: Con un estudio de los climas de la Tierra Fondo de cultura economica. 478p.

Lima R, Borém A (2018) Melhoramento de milho. 396 p. 
Lira SA, Chaves Neto A (2006) Coeficientes de correlação para variáveis ordinais e dicotômicas derivados do coeficiente linear de Pearson. Ciência \& Engenharia 15(1/2):45-53.

Pellizzaro EC, Albrecht LP, Krenchinski FH, Albrecht AJP, Migliavacca RA (2019) Redução no espaçamento do milho em solos de baixa altitude. Revista de Ciências Agrárias 42(2):211-220.

Peluzio JM, Gerominni GD, Silva JPA, Afférri FS, Vendruscolo JBG (2012) Estratificação e dissimilaridade ambiental para avaliação de cultivares de soja no estado de Tocantins. Bioscience Journal, 28(3):332$-337$.
Shull GH (1909) A pure-line method in corn breeding. Journal of Heredity 5(1):51-58.

USDA (2020) Department of Agriculture, Foreign Agricultural Services (FAS)."Corn area, yield and production". Disponível em: <https://www.nass.usda.gov/Charts_and_Maps/Crops _County/\#cr>. (Acesso em 30 Abril. 2020).

Vencovsky R, Barriga P (1992) Genética biométrica no fitomelhoramento. $496 p$. 